\title{
Financial Performance Measurement Of With Signaling Theory Review On Automotive Companies Listed In Indonesia Stock Exchange
}

\author{
Yuniningsih ${ }^{1}$, Nisrina Atika Hasna ${ }^{1}$, Barid Nizarudin Wajdi ${ }^{2}$ Sugeng Widodo \\ ${ }^{1}$ Universitas Pembangunan Nasional"Veteran" Jawa Timur Indonesia \\ ${ }^{2}$ Stai Miftahul Ula Nganjuk, Indonesia. \\ ${ }^{3}$ Universitas Wijaya Kusuma, Surabaya. Indonesia. \\ Email : yuniningsih@upnjatim.ac.id
}

\begin{tabular}{|c||c||c||}
\hline $\begin{array}{c}\text { Accepted : } \\
\text { January, 01 2018 }\end{array}$ & $\begin{array}{c}\text { Reviewed : } \\
\text { February, 09 2018 }\end{array}$ & $\begin{array}{c}\text { Published : } \\
\text { March,30 2018 }\end{array}$ \\
\hline
\end{tabular}

\begin{abstract}
Purpose: The research aims to determine the role of debt variable, corporate size and growth to the high financial performance of a company with the basis of signaling hypothesis. .

Design/methodology/approach: Analysis method used is multiple linear regression.

Findings: The results of the classical assumption test indicate that this research is free of multicollinear, heteroscedasticity and autocorrelation. The results indicate that debt results in negative direction and not significant, corporate size has a negative direction and not significant and company growth has a negative direction and significant.
\end{abstract}

Research limitations/implications: The unit of analysis is automotive companies listed on Indonesia Stock Exchange period of 2012-2016.

Practical implications: The present research has limitation that variables used can only explain $14.4 \%$ and the rest are explained by other variables beyond this study..

Originality/value: Indonesia Stock Exchange period of 2012-2016

Paper type: Research paper

Paper type : Research paper

Keywords : Corporate Size, Corporate Growth, Debt, Financial Performance, Signaling Theory

\section{INTRODUCTION}

Economy develops in many fields around the world, including in Indonesia. Every company tries to improve the activities in running the company's operations by adjusting to any changes. This is performed to maintain the survival of the company and improve the quality and able to compete with the progress that occurs both in the micro and macro sectors(Puspitasari and Harjanti, 2017; Syaifudin, 2017).

One of the main indicators of company's health can is company's financial performance. Many parties need where about the financial performance of both internal and external. Internal sectors come from company's own management, ownership of managerial institutions as well as individuals. External side come from potential investors, governments, suppliers, creditors and so on. According Yuniningsih Y, et al ., (2017), Yuniningsih Y (2012) many factors need to be considered by investors

Financial Performance Measurement Of With Signaling Theory Review On Automotive Companies Listed In Indonesia Stock Exchange

Yuniningsih, Nisrina Atika Hasna, Sugeng Widodo, Muh Barid Nizarudin Wajdi 
including the courage of investors in taking risks. Financial performance according to Muyosu ki D, Et., $\mathrm{Al}$ (2012) is the company's ability to produce new resources, at the start of daily operations during a certain period and the company's performance is measured by net income and $\mathrm{k}$ as surgery. According Yuniningsih (2017) criteria for go public company is stock price. Almajali AY, et al., (2012) states that the achievement of the company's performance is related to the authority and responsibility in achieving the objectives, legality, not against the law and in accordance with moral and ethical.

Financial performance by Muyosuki D et al., (2012) is measured by net income and operating cash which is the company's ability to generate new resources starting from day-to-day operations over a certain period. Company's financial performance needs to be assessed to see the financial performance of the company. The results of the company's financial performance assessment can be used as a guideline to take the appropriate steps in the management of the company. Brigham and Gapensky (1996) stated that the value of company's stock price is very important because the high value of the company determines the shareholders' wealth. Yuniningsih (2017) states that stock price is used to measure the value of a go public company.

Profitability is used to measure profitability of a company (Walker, 2001). One factor to use as measuring financial performance is profitability. According to Abor J., (2005) many variables are used to measure the performance of an accounting based company based on the financial statements of ROE, ROA, EPS and Net Profit Margin, market return and volatility return.

Capital structure has a very important role in determining the cost of capital. Proper capital structure will minimize the cost of capital and will ultimately impact on good financial performance as well. As Khan NK (2013) points out, capital structure has a very important role because the funds obtained are invested in assets and operated to generate income. Capital structure refers to how company finances investments whether with equity only, debt only or a combination of equity and debt.

Many factors affect financial performance in addition to stock prices. Makanga AM (2015) show that the factor of debt financing influences financial performance. Bagh T, et al., (2016) asserts that working capital along with inventory turnover variable, average turnover, and cash conversion cycle affect the company's financial performance. Khan FN et al., (2013) states that capital structure in terms of long-term debt, short-term debt and total debt affect financial performance. Financial performance of this study uses profitability proxy as measured by Return on Assets (ROA).

This study emphasizes the use of capital structure including debt, company size, and growth in sales based on reviews of Signaling Theory (Ross SA, 1977). Working capital structure deals with how company finances its assets by combining equity and its external finance from debt. According to Khan FN (2013) capital structure has an important role to determine the cost of capital. According to Velnampy, T., et al., (2012) one of the key financial strategies of a company is the successful selection and use of capital.

One variable of capital structure is debt. Debt can be short-term and long-term debt. According to Munawir (2010) that debt is a liability company to another party. Thus, debt is a company's obligation to be paid to the creditors. Debt is one source of funds, especially from external sources. External funds derived from debt greatly affect financial performance. According to Abor J (2005) profitable companies in major financing options are more dependent on debt because of anticipated high purchases. Shubita MF et al. (2012) suggest that debt has a positive effect on financial performance on the grounds that debt can increase profitability because interest payments can reduce tax payments. On the other hand, the opinion of Khan FN et al., (2013) states that debt has a negative and significant influence on financial performance with profitability proxy. Based on these two studies show different results and is a research gap of this study. This research uses signaling theory of Ross SA (1977) which states that when the company issued new debt it can provide signals about the prospects of company's improvement to shareholders and investors. Ross SA (1977) also stated that the addition of debt indicates the limited cash flow and the cost of financial burden will also increase that the manager will only issue new debts because they have confidence the company will be able to fulfill its obligations in the future.

Another factor that should be considered in assessing the company's financial performance is the size of the company. Yudhiarti R, et al., (2016) states that the size of the company can be seen from the

Financial Performance Measurement Of With Signaling Theory Review On Automotive Companies Listed In Indonesia Stock Exchange

Yuniningsih, Nisrina Atika Hasna, Sugeng Widodo, Muh Barid Nizarudin Wajdi 
type of business or business activity undertaken. Kartikasari D, et al., (2016) states that the availability of capital from investors will facilitate the company in making investments. The larger the size of the company; the easier for it in obtaining external funding in large numbers than small companies. Graham, Scott B smart, and William L Megginson (2010) states that signals will separate strong and weak firms. Strong firms are easier to signal outward than weaker firms. According Sunarto et al., (2009) the size of a company is shown by the value of the company has a positive and significant impact on profitability as a company. Based on the various opinions, the larger the size of the company, the more investors will invest in the company and the more investment will be received by the company that result in higher profitability or financial value of the company. The larger the size of the firm gives a positive signal to the company's financial performance. This is in line with those described in the signaling theory of Ross SA (1977). However, there is a research gap from some previous research on firm size and the company's financial performance. According to Ambarwati NS et al., (2015) firm size has a positive and significant impact on profitability. However, another study that is Octavia S (2015) firm size has no effect on profitability.

Another variable in this study is the company's growth that affects the company's financial performance. The growth of the company reflects how large the scope of the company especially in sales. Good corporate growth is a good signal of the company's financial outlook and performance. According to Kasmir (2010), the company's growth is a ratio that shows the company's ability to maintain its economic position amidst economic and business growth. According to Kashmir (2010) growth is based on asset growth and sales. Soliha and Taswan (2002) indicate that the growth of the company affects the value of the company. This is supported by research conducted by Safrida (2008) showing that the company's growth has a positive effect on stock price changes. It shows that where about company growth is a signal for investors to the company's financial performance. This is in accordance with the signaling theory of Ross SA (1977). According to Titman and Wessel (1988) the company's opportunity to grow is an appropriate proxy in agency costs. One indicator of company growth is the growth of assets owned by the company.

Financial performance on all companies is very necessary especially for companies that have gone public. One of which is automotive industry. Automotive industry is one of the companies that contribute in improving the Indonesian economy. According to Prasetia T.E et al. (2014) automobile companies have a very favorable prospect as transportation is one of the most important needs of society.

This study uses unit analysis of automotive sector that go public and listed in Indonesia Stock Exchange (BEI) period of 2012 -2016. There are 13 companies used as sample. In average financial performance uses profitability proxy with ROA ratio of automotive industry is shown in table below

Table 1: Average inancial performance (ROA) from 13 companies Automotive sub-sector that go public and listed on BEI year 2012-2016

\begin{tabular}{|l|l|l|l|l|l|}
\hline Average ROA value & 2012 & 2013 & 2014 & 2015 & 2016 \\
\hline Average & 8,13 & 5,52 & 4,77 & 2,64 & 1,88 \\
\hline The increase/ decrease & - & $-0,321$ & $-0,136$ & $-0,447$ & $-0,288$ \\
\hline
\end{tabular}

Source: www.idx.co.id

The above table indicates a decrease in financial performance during the study period. Decline in financial performance indicates a decline in profit or profitability of the company. Based on the research gap of the three independent variables with financial performance as well as the decrease of financial performance from the above table, both phenomena are used as the basis in this research.

\section{Literature Review and hypothesis}

Makanga AM (2015) show that the debt ratio has no significant relationship with return on assets. Related to capital structure theory of Modgiliani and Miller (1976) it does not matter how the company finances its operations. Kebewar (2012) show that debt does not affect the profitability both

Financial Performance Measurement Of With Signaling Theory Review On Automotive Companies Listed In Indonesia Stock Exchange

Yuniningsih, Nisrina Atika Hasna, Sugeng Widodo, Muh Barid Nizarudin Wajdi 
linearly and non-linearly. Khan FN . et al., (2003) argues that short-term debt, long-term debt and total debt has a significant negative relationship with profitability by using the ratio of ROI (return on investment). Pouraghajan A, et al., (2012) indicates that there is a negative relationship between the ratio of debt to financial performance, in addition there is a significant positive relationship between the size of the company with the financial performance of the company.

Debt is a liability to be paid to another party. As stated by Irawan R (2012) debt ia the obligation to surrender money, goods or services to other parties in the future which is the result transactions previously agreed upon. Debt is divided into short-term debt and long-term debt. Short-term debt is repayment of short-term nature, e.g accounts payable and taxes payable Long-term debt maturing (Thamrin, 2012). Long-term debt's payment is more than one year from the balance sheet data (Munawir, 2004). According to Ross SA (1977) when the company issued a new debt, the company has a high prospect in the data.

Company size is related to the size of a company based on the type of business and business activities undertaken (Yudhiarti R, et al., 2016). The size of the company will determine whether or not easy to obtain sources of funding both internal and external. The bigger the company the easier it is to get funds especially those that are funding from outside and vice versa. Hendriyanto (2012) and Sunarto et al ., (2009) stated that firm size reflects the company's ability to deal with uncertainty positively affecting the profitability of the company. This shows that large companies are relatively more stable in generating profits than small companies. In accordance with the signaling theory of Ross SA (1977) that the larger the size of the company will give a positive signal which means the company's financial performance is also getting better.

The size of the company's growth is related to company's financial performance. Titman and Wessel (1988) stated that investments usually occur in companies that are in a growing industry. One indicator of corporate growth is the growth of the company's assets. The greater the assets owned by the company the higher the level of profitability and the higher the company's financial value.

Hypothesis in this research are:

H1: Capital structure with variable debt positively affects the company's financial

value

H2: Capital structure with firm size variable has positive effect with firm value.

H3: Corporate growth positively affects the company's financial performance

\section{METHODOLOGY}

Research variables used consist of dependent variable of company's financial performance while independent variable is debt, firm size and company growth.

\section{Dependent variable (Y)}

Financial performance is the ability of the company generate new resources, profits started from daily operations over a period of time. Financial performance in research use profitability with proxy Return on asset (ROA). ROA formula according to Nassar S (2016) are as follows:

\section{Independent Variable $(\mathrm{X})$}

$$
\text { Return On Assets }=\frac{\text { Net Income }}{\text { Total Assets }}
$$

1). Debt $\left(X_{1}\right)$

Debt is an obligation to be paid to the other party. Debt measurement in this

study uses TDA (Total Debt to Asset) from Habib HJ et al (2016) as follows:

$$
\text { Total Debt to Asset }=\frac{\text { Total Debt }}{\text { Total Assets }} \times 100 \%
$$

2). Company Size $\left(\mathrm{X}_{2}\right)$

Company size explains about the size of the company based on the type of business and business activities undertaken. The calculation of firm size in this study uses Ln total assets according to Nugroho E. (2011) as follows:

Financial Performance Measurement Of With Signaling Theory Review On Automotive Companies Listed In Indonesia Stock Exchange

Yuniningsih, Nisrina Atika Hasna, Sugeng Widodo, Muh Barid Nizarudin Wajdi 
3). Company Growth (X3)

Company growth is an annual company growth rate as measured from the total assets of the current year with total assets of the previous year.

The growth of company's assets is measured by asset ratio Growth (AG) with the formula: (Susanto, 2010)

$$
\mathrm{AG}=\frac{\text { Total Asset } \mathrm{t}-\text { Total Asset } \mathrm{t}-1}{\text { Total assett }-1} \times 100 \%
$$

\section{Determination techniques of population and Sample}

Population in this research is automotive company which listed in Indonesia Stock Exchange period of year 2012-2016 are 13 companies.

Engineering samples uses purposive sampling method with criteria determined in this study. Based on the research criteria only 12 companies are included. Therefore, the amount of data is 12 companies X 4 years $=60$ data.

\section{Hypothesis Analysis and Testing Technique}

Analytical technique of this research uses multiple linear regression with quantitative method. This analysis technique is used to find the regression equation or influence between Capital Structure of Forest variable $\mathrm{g}$ (X1), Company Size (X2), growth of company (X3) to the variable Financial Performance of the Company (Y).

Based on the above statement the equation model used is:

$$
\mathrm{Y}=\mathrm{a}+\mathrm{b}_{1} \mathrm{X}_{1}+\mathrm{b}_{2} \mathrm{X}_{2}+\mathrm{b}_{2} \mathrm{X}_{2}+\mathrm{e}
$$

Where:

$$
\begin{aligned}
\mathrm{Y} & =\text { Financial Performance } \\
\mathrm{a} & =\text { Constants } \\
\mathrm{b}_{1} & =\text { Regression coefficient } \mathrm{X}_{1} \text { (Debt) } \\
\mathrm{b}_{2} & =\text { Regression coefficient } \mathrm{X}_{2} \text { (Company size) } \\
\mathrm{b}_{3} & =\text { Coefficient of regression X3 (Company growth) } \\
\mathrm{X}_{1} & =\text { Debt } \\
\mathrm{X}_{2} & =\text { Company Size } \\
\mathrm{X}_{3} & =\text { Company Growth } \\
\mathrm{e} & =\text { error Standard }
\end{aligned}
$$

Prior to multiple linear regression test, several tests are:

\section{Classic assumption test}

Classic assumption in this study that is considered important for this research to avoid multikolinearitas between independent variables, the absence of heteroskedastisitas causes the absence of autocorrelation (Ghozali, 2011).

\section{Coefficient of Determination $\left(\mathbf{R}^{\mathbf{2}}\right)$}

$\mathrm{R}^{2}$ is used to measure the degree of relationship between each variable $\mathrm{X}$ to variable $\mathrm{Y}$ partially (Ghozali, 2011). The formulations for test $\mathrm{R}^{2}$ (Gujarati, 2006) are as follows:

$$
\mathrm{R}^{2}=\frac{E S S}{T S S}
$$

$$
\text { Adjusted } \mathrm{R}^{2}=1-\left(1-R^{2}\right) \frac{n-1}{n-k}
$$

\footnotetext{
Financial Performance Measurement Of With Signaling Theory Review On Automotive Companies Listed In Indonesia Stock Exchange
}

Yuniningsih, Nisrina Atika Hasna, Sugeng Widodo, Muh Barid Nizarudin Wajdi 


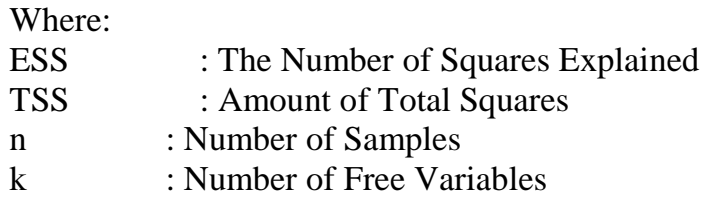

\section{Hypothesis testing}

Hypothesis test is performed by partial test (test)

The t test basically shows how far the influence of one independent variable individually explains the dependent variable variation (Ghoz ali, 2011). Thet test formula then uses the following formula: (Gujarati, 2006).

$$
\mathrm{t}=\frac{\beta \mathrm{n}}{\mathrm{s} \beta \mathrm{n}}
$$

Where:

$\mathrm{t} \quad=$ Following the function $\mathrm{t}$ with degrees of freedom (df).

$\mathrm{Bn}=$ Regression coefficients of each variable.

$\mathrm{S} \beta \mathrm{n}=$ Standard error of each variable.

\section{RESULTS AND DISCUSSION}

Before doing multiple linear regression test, classical assumption is teted. The test is performed to see if this study is free from multicollinality, heterescedasticity and autocorrelation. The results of the classic assumption test are presented in the following table.

Table 2 : Result of Classic assumption test

\begin{tabular}{|l|l|l|}
\hline \multicolumn{1}{|c|}{ Information } & Result & Criteria \\
\hline Multikolinearitas (VIF) & & $<10$ \\
$-\quad$ Debt (X1) & 1.050 & $\begin{array}{l}\text { no multicollinear } \\
\text { no multicollinear } \\
\text { no multicollinear }\end{array}$ \\
\hline$\quad$ Company Size (X2) & 1.081 & \\
\hline Heteroskedastisitas (sig 2-tailed)(Rank spearman) & & $>0.05$ \\
$-\quad$ Debt (X1) & & no heteroskedasticity \\
Company Size (X2) & 0.527 & no heteroskedasticity \\
Company Growth (X3) & 0.861 & \\
\hline Autocorrelation (Durbin Watson) & 0.787 & no autocorrelation \\
& & \\
\hline
\end{tabular}

Source : data processed

Based on the above table, it shows that this study meets three classical assumptions. The first classical assumption is multicollinear with three variables shows the VIF result less than 10 . Therefore, the three variables show no multicollinear or no correlation between the three independent variables of this study. The three variables also shows the absence of heteroskedasticity because the statistical results shows value of more than 0.05 . Heteroskedasticity test is performed using Rank Spearman. Likewise, the results of autocorrelation using Durbin Watson shows the value of 0.973 which is located between criteria set value of $<-2$ to $>2$ so this research free of autocorrelation. Based on these three results, it can be concluded that this study meets the classical assumption.

Financial Performance Measurement Of With Signaling Theory Review On Automotive Companies Listed In Indonesia Stock Exchange

Yuniningsih, Nisrina Atika Hasna, Sugeng Widodo, Muh Barid Nizarudin Wajdi 
Table 3 shows the results of statistical tests to determine the effect of each variable Debt, Size of the company and company growth to financial performance of the company. Statistic test is conducted to know whether the research results in accordance with the hypothesized. Statistical test results are presented in the following table.

Table 3 : Result of multiple linear regression test

\begin{tabular}{|l|c|c|c|}
\hline \multirow{2}{*}{ Information } & \multicolumn{2}{|l|}{ Result } & B \\
\cline { 2 - 4 } & R Square & Significance \\
\hline R Square & 0.144 & & \\
\hline Coefficient & & & \\
- Constant & & 10.234 & 0.047 \\
- Debt (X1) Growth & & -3.560 & 0.240 \\
- Company Size (X2) & & -0.022 & 0.947 \\
- Company G3) & -9.973 & 0.008 \\
(X3) & & & \\
\hline
\end{tabular}

Source : data processed

Based on the above table $\mathrm{R}^{2}$ or $\mathrm{R}$ Square is 0.144 showing that for $14.4 \%$ this study is explained by the debt variable_X1, Size of the Company_X2 and Growth of the Company_X3 while the rest of 85.6\% is explained by other variables outside the independent variable used.

This study uses a level of significance of 0.05 or $5 \%$. H1 hypothesize that debt (X1) has a positive influence on the financial performance of the company. The results show debt with beta of - 3,560 and significance of 0.240 The result of the significance of the debt is greater than the significance level of $5 \%$. These results indicate that debt has a negative direction and has no effect on the financial performance of the company. Thus, the results of research for the variable debt are not in accordance with the hypothesis.

The results of this study are not in accordance with the statement of Ross SA (1977) in signaling theory stating that if the company adds debt by issuing new debt, it will signal that the prospect of the company in the future will be better. This study is also incompatible with a research conducted by Khan FN (2003) stating that short-term debt, long-term debt and total debt have a negative relationship with profitability. The results of this study in accordance with the results Kebewar's research (2012) which shows that debt does not affect the profitability. The results of this study indicate that the addition of debt does not affect the financial performance of companies. This is because the addition of debt will increase the burden of capital costs, especially those sourced from debt. But the higher the debt and the higher burden of debt burden borne by the company in this study is not related to the declining financial performance of the company. The decline in corporate financial performance is likely due to the declining profitability rate because the increase in product prices is not proportional to the increase in other costs. Other costs other than the cost of debt include the cost of production, sales costs, marketing costs and other costs are higher then it will lead to a negative effect on the financial performance of the company.

H2 hypothesize that Company Size (X2) has a positive effect on the company's financial performance. The results showed that firm size with beta of -0.022 and significance of 0.947 and greater of level of significance 0.05 . The size of the company in this study shows the negative direction and does not affect the financial performance of the company. So the result of research for company size variable not match with which is hypothesized.

Results of research on this variable do not correspond with the research conducted by Ambarwati NS et al., (2015) and Sunarto et al., (2009) finding significant positive effect of firm size and profitability. This result is also inconsistent with the opinion of the signaling theory of Ross SA (1977).

Financial Performance Measurement Of With Signaling Theory Review On Automotive Companies Listed In Indonesia Stock Exchange

Yuniningsih, Nisrina Atika Hasna, Sugeng Widodo, Muh Barid Nizarudin Wajdi 
Basically Ross SA (1977) states that the larger the size of the company the more signal that the company has a good financial performance. This is because big company makes the company's access to capital gain can be performed more easily. The ranges of markets are more broadly that will increase profitability. The results of this study indicate that firm size does not affect the financial performance of the company. This result is in accordance with a research conducted by Octavia $S$ (2015) stating that firm size has no effect on profitability. The results of this study indicate that many other variables play a role in determining the company's financial performance. The size of the company is only a small part of many factors that affect the company's financial performance.

The larger the company the more management manages the company. The more management in the company there is the possibility of agency conflict management. Agency conflict will decrease the company's financial performance. Company's ownership is also crucial role in determining financial performance. Large size of the company does not cause the lower the company's financial performance because the decline in financial performance is likely caused by factors other than the variable used is very instrumental in determining the company's financial performance.

H3 hypothesize that company growth (X3) has a positive effect on the company's financial performance. The results of this study indicate that the growth of companies with beta of -9.973 and significance of 0.008 and smaller than the level of significance 0.05 . Although the growth of the company affects the company's financial performance but the direction is not in accordance with the hypothesis. Therefore, the results of research for variable growth of companies are not in accordance with the hypothesis.

The results of this study are not in accordance with the research conducted by Soliha E and Taswan (2002), Safrida (2008) which indicates that company growth has a positive effect on the value of the company. In addition, it is also not in accordance with the signaling theory of Ross SA (1997) stating that good informtion provide a positive signal for the investor. Attributed to the growth of the company, the company's high growth shows good financial performance as well. This study is in accordance with research from Ramezani, Soenen and Jung (2002) where maximizing the company's growth cannot maximize the profitability of the company. Fitzsimons, Steffes, Douglas (2005) showed inconsistent relationship between growth and profitability.

Companies in a period of growth always require funding whether funds come from debt or from equity. The high growth of the company in this study shows the tendency of the funds obtained to be used for the purchase of assets or investment. As the company grows, the greater the need for funds to expand and the greater the burden the company will incur in expanding. Thus, high investment expansion, especially in assets, will reduce the profitability that will be accepted which causes the financial performance becomes lower and vice versa.

\section{CONCLUSION}

This study emphasizes the measurement of corporate financial performance by using debt, firm size and company growth. The results of this study indicate that debt and firm size have no significant effect and have a negative direction with the company's financial performance. This shows that the decrease of the company's financial performance is not caused by the large amount of debt and company size but possibly due to the higher cost of goods sold, the cost of sales, marketing, agency conflict and other factors that occur in the company. Corporate growth has a significant effect and has a negative direction on the company's financial performance. This indicates that the growth of the company affects the size of the company. The greater the company's growth the smaller the level of profitability gained. This means that funds obtained whether derived from debt or equity is more widely used to finance investment expansion resulting in reduced profitability obtained by the company

\section{LIMITATIONS}

The study has limitations in the independent variables used so as to influence the small contribution in explaining the dependent variable is the company's financial performance. Further research should be developed for wider research variables that independent variables can play a big role in explaining variable

Financial Performance Measurement Of With Signaling Theory Review On Automotive Companies Listed In Indonesia Stock Exchange

Yuniningsih, Nisrina Atika Hasna, Sugeng Widodo, Muh Barid Nizarudin Wajdi 
financial performance of the company. The unit of analysis can be applied to other sectors outside the automotive sector.

\section{ACKNOWLEDGMENTS}

We as the authors express our gratitude to the UPN "Veteran" of East Java who has provided an opportunity in conducting this research.

\section{REFERENCES}

Ambarwati, N.S. 2015. Pengaruh Modal Kerja, Likuiditas, Aktivitas, dan Ukuran Perusahaan Terhadap Profitabilitas pada Perusahaan Manufaktur yang Terdaftar di Bursa Efek Indonesia. E-Journal S1 Ak Universitas Pendidikan Ganesha, Jurusan Akuntansi Program S1 (Volume 3 No 1 Tahun 2015).

Abor, J. 2005. The Effect of Capital structure on Profitability: An Empirical Analysis of listed Firms in Ghana. University of Ghana Business School, Legon. Ghana.

Almajali, A.Y, et al.,. 2012. Factors Affecting the financial performance of Jordanian insurance companies listed at Amman Stock exchange. Journal of Management Reseach, ISSN 1941-899X, 2012, Vol 4, No 2.

Bagh T, et al., .2016. The impact of working capital management on Firms Financial Performance: Evidence from Pakistan. International Journal of Economics and Financial Issues, ISSN: 2146-4138, 2016, 6(3), 1097-11-5

Brigham and Gapenski. 1996. Intermediate Financial Management”. Fifth Edition, New York: The Dryden press.

Ghozali, 2011. Aplikasi Analisis Multivariat dengan Program SPSS. Badan Penerbit Universitas Diponegaoro. Semarang.

Ghozali, Imam. 2006. Structural Equation Modelling Metode Alternatif dengan partial least square (PLS). Semarang: Badan Penerbit UNDIP.

Gujarati. 2006. Dasar-dasar Ekonometrika. Erlangga. Jakarta.

Graham, Scott B smart, dan William L Megginson. 2010. Definisi Teori Sinyal. http://ioaddakhil. Blogspot.com/2014/02/pengertian-teori sinyal.html.

Harahap, Syofyan Syahri. 2013. Analisis Atas Laporan Keuangan. Jakarta: Raja Grafindo Persada

Hendriyanto. 2012. Tingkat kesulitan keuangan perusahaan dan konservatisme akuntansi di Indonesia. Jurnal Ilmiah Mahasiswa Akuntansi di Indonesia-Vol. 1, No. 3, Mei 2012.

Habib H.J. et al.,.2016. Impact of Debt on Profitability ofFirms: Evidence From Non_Financial Sector of Pakistan. City University Research Journal, Vol 06 Number 01 January 2016. PP 70-80.

Irawan R. 2012. Pengaruh Hutangterhadap Profitabilitas Perusahaan Telekomunikasi yang Go Public di BEI 2006-2011. JUrusan Manajemen Fakultas Ekonomi dan Ilmu Sosial Universitas Islam Negeri Sultan Syarif Kasimriau Pekanbaru

Khan, F.N. 2013. Impact of Capital Structure on Firm Financial Performance: A Case of The Pakistani Engineering Firms Listed On KSE. University of Sargodha Sub-Campus Bhakkar.

Kumaraswamy.2016. Impact of Working Capital on Financial Performance of Gulf Cooperation Council Firms, International Journal of Economics and Financial Issues, ISSN: 2146-4138, 2016, 6(3), 11361142. Department of Economics and Finance, College of Business Administration, University of Bahrain, Kingdom of Bahrain.

Kartikasari D, et al.,.2016. The Effect of Leverage and Form size to Profitability of Public Manufacturing Companies in Indonesia. Department of Management and Business, Batam State Polytechnic,

Financial Performance Measurement Of With Signaling Theory Review On Automotive Companies Listed In Indonesia Stock Exchange

Yuniningsih, Nisrina Atika Hasna, Sugeng Widodo, Muh Barid Nizarudin Wajdi 
Batam. Indonesia International Journal of Economics and Financial Issues, ISSN: 2146-4138,2016, 6(2), 409-413

Kasmir. 2010. Pengantar Manajemen Keuangan. Jakarta: Kencana Pranada Media Group.

Kebewar Mazen. (2012). The Effect of Debt on Corporate Profitability Evidence from French Service Sector.

Munawir. 2010. Analisa Laporan Keuangan. Yogyakarta: Liberti.

Munawir. 2004. Analisis Laporan Keuangan. Edisi ke 4. Liberty Yogyakarta.

Makanga, A.M. 2015. The Effect of Debt Financing on The Financial performance of Companies Listed at The Nairobi Securities Exchange. University of Nairoby,

Muyosuki D et al., .2012. The Impact of Credit Risk Management on The Financial Performance of Bank in Kenya for The Period 2000-2006. International Journal of Business and Public Management. iSSN:2223-6244. Vol. 2(2):72-80.

Nassar, S. 2016. The Impact of Capital Structure on financial performance of the firms: Evidence from Borsa Istambul. Journal of Business \& Financial Affairs. Mamara University, Institute of Social Science, Accounting and Finance Department, Istambul, Turkey.

Nugroho E. (2011). Analisis pengaruh likuiditas, pertumbuhan penjualan, perputaran modal kerja, ukuran perusahaan dan leverage terhadap profitabilitas perusahaan. Skripsi . Fakultas Ekonomi Universitas Diponegoro Semarang. 2011.

Octavia, S. 2015. Pengaruh Indikator Pengelolaan Modal Kerja dan Ukuran Perusahaan Terhadap Profitabilitas. Sekolah Tinggi Ilmu Ekonomi Perbanas Surabaya.

Pouraghajan A, et al., .2012. The Relationship Between Capital Structure and Firm Performance Evaluation Measure: Evidence from the Tehran Stock Exchange international Journal of business and Commerse., Vol 1 No. 9:May 2012 (166-181). ISSN:2225-2436. Department of accounting, Qaemshahr Branch, Islamic Azad University, Qaemshahr. Iran.

Prasetia T.E. et al., (2014). Struktur Modal, Ukuran Perusahaan dan Risiko Perusahaan Terhadap Nilai Perusahaan terhadap Nilai Perusahaan Otomotif Yang Terdaftar Di BEI, Fakultas Ekonomu Dan Bisnis, Jurusan Manajemen Universitas Sam Ratulangi Manado

Ross. S.A. 1977. The Determination of Financial Structure: The Incentive-Signaling Approach. The Bell Journal of Economics, 8. 23-40.

Ramezani C, Soenen L and Jung A. (2002). Growth, Corporation Profitability, and Shareholder Value Creation.

Soliha E dan Taswan. 2002. Pengaruh Nilai Perusahaan Serta Beberapa Faktor Yang Mempengaruhinya. Jurnal Bisnis dan Ekonomi. Vol.9. No2. September:149-163.

Safrida, Eli. 2008. Pengaruh Struktur Modal dan Pertumbuhan Perusahaan pada Perusahaan Manufaktur Di BEI. Thesis. Medan: Universitas Sumatera Utara.

Shubita M.F et al., .2012. The Relationship Between Capital Structure and Profitability. International Journal of Business and Socual Science, Vol. 3 No. 16 (Special Issue-August 2012). Departement of Accounting Amman Arab University Amman-Jordan.

Sunarto et al., 2009. Pengaruh Leverage, Ukuran dan Pertumbuhan Perusahaan terhadap profitabilitas. TEMA Vol 6 Edisi 1, Maret 2009 hal 86-103 Program Pascasarjana Universitas Stikubank.

Susanto, Catur. 2010. Pengaruh Faktor-faktor pertumbuhan dan rasio hutang perusahaan terhadap profitabilitas. Malang: Universitas Brawijaya

Titman, S and R. Wessel. 1988."The Determinant of Capital Structure Choice”. The Journal of Finance". 43:1-19.

Financial Performance Measurement Of With Signaling Theory Review On Automotive Companies

Listed In Indonesia Stock Exchange

Yuniningsih, Nisrina Atika Hasna, Sugeng Widodo, Muh Barid Nizarudin Wajdi 
Thamrin Y. (2012). Analisis Currrent Ratio (CR) dan Debt Equity Ratio (DER) terhadap Return Saham Perusahaan Manufaktur yang Terdaftar di Bursa Efek Indonesia. Skripsi Jurusan Manajemen Fakultas Ekonomi dan Bisnis Universitas Hasanudin Makasar. 2012.

Velnampy, T. et al.,. 2012. The Relationship between Capital Structure \& Profitability. Global Journal of Management and Business Reseach. Volume 12 Issue 13 Version 1.0 year 2012, Online ISSN: 22494588\&vPrint ISSN:0975-5853.

Walker. 2001. Exploring the Human Capital Contribution to Productivity, Profitability and the Market Evaluation of the firm, available on :http://wwwlib.umi.com/dissertations.

Yuniningsih Yuniningsih, et al.,.2017. An analysis of decision making in the stock investment. Jurnal Ekonomi dan hokum Islam, Vol 8, No 2. 2017.

Yuniningsih. 2017. Seberapa besar kepemilikan saham berperan dalam penentuan nilai perusahaan dengan tinjauan agency theory. Jurnal Darussalam,. Jurnal pendidikan, komunikasi dan pemikiran Hukum islam Vol. IX, No 1: 107-115. September 2017. ISSN: 1978-4767 (cetak), ISSN:2549-4171 (online).

Puspitasari, E. and Harjanti, W. (2017) 'Meaningful Experience Of Motivation To Power Seller With Orientation On Consumer Satisfaction For Identification Of Employee Benefits In The Textile Sales In South Surabaya', IJEBD (International Journal Of Entrepreneurship And Business Development), $1(1)$, pp. 1-22.

Syaifudin, A. (2017) 'The Impact of Creativity and Innovation on Increasing Micro Enterprise Income PKL Gading Fajar Sidoarjo', IJEBD (International Journal Of Entrepreneurship And Business Development), 1(1), pp. 88-98. Available at: http://jurnal.narotama.ac.id/index.php/ijebd/article/view/349 (Accessed: 1 November 2017).

Yuniningsih Y (2012). Insider Ownership, free cash flow dan dividend Policy Perusahaan Manufaktur Terdaftar Di BEJ. Jurnal Riset Ekonomi dan Bisnis 8 (1). 20-25, 2012.

Yudhiarti R, et al., 2016. Analisis faktor-faktor yang mempengaruhi struktur modal pada perusahaan manufaktur yang terdaftar di bursa Efek Indonesia periode tahun 2010-2014. Journal of management, Volume 5, Nomor 3, tahun 2016, Halaman 1-13, ISSN (online). 2337-3792

Financial Performance Measurement Of With Signaling Theory Review On Automotive Companies Listed In Indonesia Stock Exchange

Yuniningsih, Nisrina Atika Hasna, Sugeng Widodo, Muh Barid Nizarudin Wajdi 